HSTC Bulletin

Journal of the History of Canadian Science, Technology and Medecine

hstc

Revue d'histoire des sciences, des techniques et de la médecine au Canada

bulletin

\title{
On Changing Gears
}

Volume 4, numéro 3-4 (15-16), june 1980

URI : https://id.erudit.org/iderudit/1081460ar

DOI : https://doi.org/10.7202/1081460ar

Aller au sommaire du numéro

Éditeur(s)

HSTC Publications

ISSN

0228-0086 (imprimé)

1918-7742 (numérique)

Découvrir la revue

Citer ce document

(1980). On Changing Gears. HSTC Bulletin, 4(3-4), 1-1.

https://doi.org/10.7202/1081460ar

All Rights Reserved (c) Canadian Science and Technology Historical Association / Ce document est protégé par la loi sur le droit d'auteur. L’utilisation des Association pour l'histoire de la science et de la technologie au Canada, 1980 services d'Érudit (y compris la reproduction) est assujettie à sa politique d'utilisation que vous pouvez consulter en ligne.

https://apropos.erudit.org/fr/usagers/politique-dutilisation/

Cet article est diffusé et préservé par Érudit.

Érudit est un consortium interuniversitaire sans but lucratif composé de l'Université de Montréal, l'Université Laval et l'Université du Québec à

Montréal. Il a pour mission la promotion et la valorisation de la recherche.

https://www.erudit.org/fr/ 


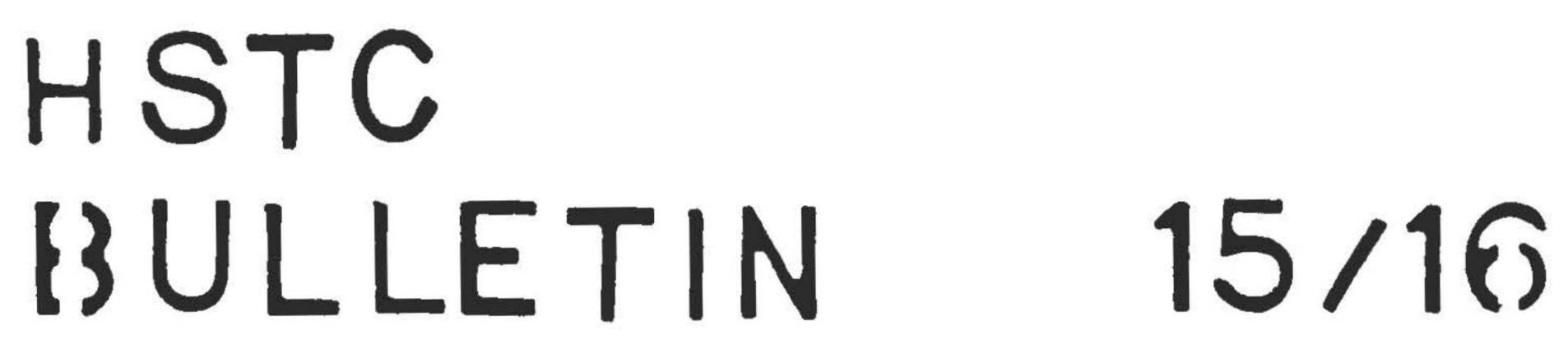

June 1980 Juin

\section{ON CHANGING GEARS}

It is not without a great deal of trepidation on our part that we end four years of producing a newsletter and launch a journal. The change is somewhat like giving up a bicycle for a sportscar: you are vaguely aware of how to drive it but aren't sure you can keep up the payments or obtain enough fuel for it. Still, as the teenager gives up a bicycle for a car, we believe that our field is emerging from its adolescence and now has more sophisticated requirements. When Norman Ball and I began producing the Bulletin in 1976, we put together a list of some fifty possible readers. Since then the list has more than tripled and is still growing. If this newsletter has played a art in bringing together a loose network of researchers, then we feel e have accomplished something considerable.

The newsletter will not die; it will be incorporated into the journal. While we have always had just enough money and help from a few friends to get out four papers a year, we face rather more formidable odds in the new venture. Initially, we hope to finance the journal from subscriptions and advertisements. Of course, if we are not to price the journal out of existence, we must continue to rely upon cheaper format, but what counts is what is between the covers. Arnold Roos and $I$, aided by a number of advisory editors, intend to purvey quality articles, but this will require (at least at first) an act of faith on the part of the scholarly community. It will take some courage to publish an article in a journal that no one has ever heard of but we invite you to take the plunge. Only time will tell whether this venture was premature, but Arnold and I are enternal optimists and we look forward to your assistance, contributions, and criticisms.

Quarterly Newsletter for the History of Science and Technology of Canada
Publication trimestrielle pour l'histoire des sciences et de la technologie au Canada 